\title{
Problems Related to the Commencement Date of the Obligation to Use in the Action for Revocation due to the Non-use of a Trademark and Solution Proposals
}

\author{
Sıtkı Anlam Altay* (1)
}

\begin{abstract}
Certain developments that occurred consecutively in the field of Turkish Trademark Law have rendered the outcome of the violation of the obligation to use a trademark, which exists since the Decree No.556 on Protection of Trademarks (the "Trademark Decree"), debatable. As is known, the non-use of a trademark for a period of five years leads to the sanction of revocation pursuant to the Trademark Decree art. 14 and the Industrial Property Law art. 9. The Paris Convention and TRIPS Agreement also regulate this sanction optionally. The problem at hand arose due to a gap of mere four days between the revocation of the Trademark Decree Art. 14 via Constitutional Court decision, and the date when IPL came into force and said provision was re-enacted through IPL art. 9. As a result of the Constitutional Court's decision, as of 06.01.2017, the obligation to use the trademark cannot be imposed on the proprietor. As a consequence of the principle of non-retroactivity of laws, IPL art. 9 imposes an obligation to use beginning from the enforcement date of this law. Consequently, since there was no obligation to use for proprietor on the enforcement date, the obligation to use would have commenced on 10.01.2017. This situation is in favor of proprietors who seek to obtain rights based on the trademark they do not use, however to the detriment of an aggrieved party. Although the scholars have different opinions and solution proposals, these proposals seem to be inadequate, unless a provision governing enforcement is added to IPL and it is stated that the five-year period will be calculated considering the period before the enforcement date of the IPL.
\end{abstract}

\section{Keywords}

Trademark, Revocation due to the non-use, Reasons for revocation, Qualification of the trademark right, Relationship between revocation and defenses

Markanın Kullanılmaması Nedeniyle Hükümsüzlüğü Davasında Markayı Kullanma Yükümlülüğünün Başlangıç Anına İlişkin Sorunlar ve Çözüm Önerileri

Öz

Türk Marka hukukunda ard arda yaşanan bazı gelişmeler, Markaların Korunması Hakkında KHK zamanından beri var olan kullanma yükümüne aykırı davranışın sonucunu tartışılır hale getirmiştir. Bilindiği üzere, markanın beş yıl boyunca kullanılmaması, 556 sayılı KHK md 14 ve SMK md 9'a göre iptal yaptırımını beraberinde getirmektedir. Paris ve TRIPS Anlaşmaları da seçimlik olarak bu yaptırımı öngörmektedir. Sorun, Anayasa Mahkemesi kararı ile 556 sayılı KHK md 14’ün iptal edilmesi ve sadece dört gün sonra yürürlüğe giren Sınai Mülkiyet Kanunu md 9 ile bu düzenlemenin yeniden getirilmesi ile ortaya çıkmıştır. Anayasa Mahkemesi kararının bir sonucu olarak, 06.01.2017 tarihi itibariyle markayı kullanma yükümü artk marka sahibine yüklenemeyecektir. Kanunların geriye yürümezliği ilkesinin bir sonucu olarak

\footnotetext{
* Correspondence to: Sıtkı Anlam Altay (Assoc. Prof. Dr.), Galatasaray University, Faculty of Law, Department of Commercial Law, Istanbul, Turkey. E-mail: SALTAY@gsu.edu.tr ORCID: 0000-0002-0061-4729

To cite this article: Altay AA, "Problems Related to the Commencement Date of the Obligation to Use in the Action for Revocation due to the Non-use of a Trademark and Solution Proposals" (2019) 77(2) İstanbul Hukuk Mecmuası 897.

https://doi.org/10.26650/mecmua.2019.77.2.0099 
ise SMK md 9, yürürlük tarihinden itibaren bir kullanma yükümü getirmektedir. Neticede, SMK'nın yürürlüğe girdiği tarihte, marka sahibi için kullanma yükümü bulunmadığı için, kullanma yükümü ancak 10.01.2017 tarihinden itibaren başlayacaktır. Bu ise, kullanmadığı markaya dayanarak hak elde etmeye çalışan marka sahipleri lehine ve fakat bundan zarar gören kişiler aleyhine bir sonuçtur. Bu konuda doktrinde farklı görüşler ve çözüm önerileri bulunmakla beraber, SMK'ya yürürlük hükmü eklenmediği ve beş yıllık sürenin SMK'nın yürürlük tarihinden önceki dönem de göz önünde bulundurularak hesaplanacağı belirtilmediği sürece, çözüm önerileri yetersiz kalacak gibi görünmektedir.

\section{Anahtar Kelimeler}

Marka, Kullanmama nedeniyle iptal, İptal sebepleri, Marka hakkının niteliği, İptalin def'ilerle ilişkisi 


\section{Problems Related to the Commencement Date of the Obligation to Use in the Action for Revocation due to the Non-use of a Trademark and Solution Proposals}

\section{Introduction}

Within the scope of the Customs Union Agreement, which was signed between Turkey and the European Union, regulations on industrial rights have been achieved through decree laws, in order to ensure compliance with respect to intellectual rights. One part of this harmonization process was the Decree No.556 on Protection of Trademarks ("Trademark Decree"). Many articles of this legislation, which satisfied a great need in its time, were revoked in the context of the evaluation of industrial rights within the scope of property rights ${ }^{2}$. In fact, art. $7 / 1-1^{3}$, art. $14^{4}$, art. $16 / 5^{5}$, and art. $42 / 1-\mathrm{c}^{6}$ of the Trademark Decree were revoked through the decisions of the Constitutional Court on different dates. These provisions were revoked on the grounds that, industrial property rights fall within the scope of intangible goods, thus they are property rights governed under article 35 of the Constitution, and that the rights and obligations of an individual, without prejudice to martial law and state of emergency regulated in article $91 / 1$, cannot be regulated by decree laws, rather they have to be regulated by law.

On one hand the need to regulate industrial rights by law, and on the other the need for harmonization with the evolving EU legislation, have required the revision of legislation provided under decree laws and to enact them as laws after necessary amendments are made. Besides, some amendments are required in these regulations to satisfy the developing needs. The Industrial Property Law dated 10.01.2017 and numbered 6769 (the "IPL") was prepared and enacted as a result of these requirements? In fact, the EU Commission stated in its 2018 Turkey Progress Report dated 17.04.2018 that Turkey is preparing well in the field of intellectual property law ${ }^{8}$.

However, a major problem arose between the two legislations in this process, especially in terms of the consequence of the non-usage of a trademark for a period

Decree on Protection of Trademarks, Decree Number: 556, Official Gazette (“OG”) 27.6.1995/22326.

2 For detailed information on the revoked articles and their effects see: Ali Pasl1, 'Anayasa Mahkemesi'nin Son Dönemdeki İptal Kararlarının Marka Hukukumuza Etkisi: Boşluk Var mı?' (2016) 12(46) Legal Intellectual and Industrial Property Rights Review 491, 492 ff; Ali Paslı, Uluslararası Antlaşmaların Türk Marka Hukukunun Esasına İlişskin Etkileri (Vedat 2014) $48 \mathrm{ff}$.

It is revoked by the Constitutional Court decision, 33/50, 27.05.2015.

It is revoked by the Constitutional Court decision, 148/189, 14.12.2016.

It is revoked by the Constitutional Court decision, 49/46, 13.05.2015.

It is revoked by the Constitutional Court decision, 147/75, 09.04.2014.

Industrial Property Law, Law Number: 6769, Date of Enactment: 22.12.2016, OG 10.1.2017/29944.

https://ec.europa.eu/neighbourhood-enlargement/sites/near/files/20180417-turkey-report.pdf, 69. For detailed information, see Önder Erol Ünsal, '2018 yılı Avrupa Birliği İlerleme Raporu Fikri Mülkiyet Hukuku Bölümü' <https://iprgezgini. org/2018/04/18/2018-yili-avrupa-birligi-ilerleme-raporu-fikri-mulkiyet-hukuku-bolumu/> accessed 26 June 2019. 
of five years. On one side, the court decision revoking art. 14 of the Trademark Decree came into force on 06.01.2017 whereas on the other side, the same provision was enacted as art. 9 of the IPL dated 10.01.2017 and numbered 6769. Although the provision appears to remain intact, since Trademark Decree Art.14 has been revoked, the commencement date of the obligation to use the trademark has caused controversy among scholars and in practice.

In this article, after examining the reason for the occurrence of the problem, different opinions will be conveyed; followed by the evaluation of a reasonable solution for this problem.

\section{Obligation to Use a Trademark}

Pursuant to the IPL, the protection on a trademark begins with the registration of the trademark. However, this does not imply or represent that an unregistered trademark will not be protected. An unregistered trademark is also protected, but pursuant to the IPL, the trademark must be registered to obtain rights based on a trademark $^{9}$. Under both the IPL and the Trademark Decree, which is no longer in force, the trademark must be put into genuine use in order for the person to retain its right on a registered trademark. If a trademark is registered only, this is not sufficient to exercise all rights granted to the trademark either. Pursuant to the IPL art. 9/1, If, within a period of five years following the date of registration, the trademark has not been put to genuine use in Turkey by the trademark proprietor in connection with the goods or services in respect of which it is registered, or if such use has been suspended during an uninterrupted period of five years, the trademark shall be revoked, unless there are proper reasons for non-use. In accordance with the EU regulations, the IPL regulates that the non-use of a trademark results in its revocation (IPL art. 26/1-a, corresponding to art. 18 of the EU trademark regulation dated 14.06.2017 and numbered 2017/1001), and that in case of objection by an earlier trademark proprietor to a recent trademark application, as a result of the request of the person whose application is objected to, the proprietor has to prove that the trademark has been put into genuine use in Turkey in terms of goods or services subjected to the objection of the trademark, or that the proprietor has justifiable reasons to its nonuse. (IPL art. 19/2, Regulation No. 2017/1001 art. 47/2). In addition, a person faced with infringement proceedings can assert a defense that the person who accused the former has not used its trademark for a period of five years, and in this situation the

\footnotetext{
In some cases, an unregistered trademark is also protected. For example, pursuant to art. $6 / 3$ of the IPL, if any right has been obtained of an unregistered trademark or any other mark used in trade before the date of application or the date of priority, the trademark application shall be rejected upon opposition by the holder of the said mark. Likewise, in accordance with Art. 25/1 of the IPL, the court shall decide on the invalidity of a trademark if one of the cases listed in Article 6 exists. In other words, even if a trademark is unregistered, if the right is granted through usage, the person based on this unregistered trademark may object to the registration of another person's trademark or even if the trademark is registered, the proprietor of the unregistered trademark may also demand the invalidity of this trademark.
} 
date of the lawsuit shall be taken into account for determining the five year period related to the use (IPL art. 29/2).

Therefore, in order to maintain the right on a trademark, its use is mandatory. If a trademark cannot be used for consecutive five years without interruption or its use is suspended, the trademark will be revoked. For a trademark to be considered used, as it is seen obviously from IPL art. 9/1, (1) the trademark should be used in a certain geographical area, which has been determined as Turkey; (2) use of the trademark must not have been suspended for a certain period of time, which is determined as 5 years; and (3) the trademark must be put into genuine use ${ }^{10}$.

\section{Examination of the Problem}

The obligation to use a trademark is not a new regulation introduced by the IPL. The obligation to use was regulated by Trademark Decree art.14 and also it is included in the EU regulations, the Paris Convention and TRIPS. The basis of these legislations is the obligation to use a trademark. Although this obligation is regulated in different ways, the main point is that a trademark only provides rights to the proprietor if it is used $^{11}$. The text of article 14/1 of the Trademark Decree before its revocation through the Constitutional Court's ("ConC") decision dated 14.12.2016"12 read: If a trademark is not used within a period of five years from the date of registration, without a justifiable reason, or if the use is suspended for a period without interruption of five years, the trademark shall be revoked.

Only four days after the publication of this decision, the IPL entered into force on 10.01.2017. IPL art. 9/1 is almost a repetition of the abrogated Trademark Decree art 14/1: If, within a period of five years following the date of its registration, a trademark has not been put to genuine use in Turkey by the trademark proprietor in connection with the goods or services in respect of which it is registered, or if such use has been suspended during an uninterrupted period of five years, the trademark shall be revoked, unless there are proper reasons for non-use.

If solely the regulations provided under the Trademark Decree and the IPL are taken into consideration, it can be said that the legal order has not changed, however, with the revocation of Trademark Decree art. 14, beginning from 06.01.2017, the obligation to use the trademark no longer exists. As a result of the revocation of Trademark

10 Art. 9/2 and 3 of the IPL identify the meaning of the usage of a trademark. Since the genuine use of a trademark is not the subject of this study, further explanation will not be provided in this regard. However, for detailed information about the genuine use of the trademark, see Hamdi Yasaman, Sitkı Anlam Altay, Tolga Ayoğlu, Fülürya Yusufoğlu and Sinan H. Yüksel, Marka Hukuku 556 sayılı KHK Şerhi (Vedat 2004) 628 ff.

11 As will be assessed in further detail below, the Paris Agreement and TRIPS do not make the use of a trademark mandatory. However, in the event a member state foresees such an obligation, they regulate the consequence to this fact. As Turkey is not an EU member state, it is not possible for the EU Regulation to directly apply within Turkey.

12 For the Constitutional Court decision 148/189, 14.12.2016. 
Decree art. 14, revocation or invalidity of a trademark is no longer demandable due to its non-use. As is known, laws begin to apply from their enforcement date and in principle, they apply only to the cases that have occurred after the enforcement date. Hence, a proprietor can only be put under such an obligation after 10.01.2017, the enforcement date of the IPL, since there is no obligation to use the trademark at its enforcement date.

From this point of view, it is necessary to evaluate the problem caused by the revocation decision and the enactment of the same provision after four days in line with the revoked provision, as well as its reflections to the discussions among scholars. The reason is that, after the ConC decision, it is no longer mandatory to use a trademark and under the IPL art. 9, the legislation foresees that a trademark should be revoked if not used for a period of five years. In this case, for a trademark that has not been used before enforcement of the IPL (for example a brand that has not been used for 7 years), since it has not been used without a justifiable ground for five years, can it be revoked immediately after 10.01.2017? Thus, the main problem that arises with the revocation decision of ConC and the enforcement of the IPL is the determination of the beginning date of non-use. In other words, an "action for revocation" lawsuit due to non-use which is filed between 06.01.2017 and 09.01.2017 is bound to be rejected; because the provision that foresees revocation on the grounds of non-use is no longer in force on the date of initiation of the lawsuit. On the other hand, in a lawsuit initiated after 10.01.2017, the problem is the determination of the date when the 5-year period of non-use will begin.

There are three opinions on this issue. Pursuant to one opinion, as a result of the ConC's decision, the 5-year period will be taken into consideration only from the enforcement date of the IPL, based on the principle of non-retroactivity of laws; the period of "non-use" before the enforcement date of the IPL will not be considered. Accordingly, until 10.01.2022, revocation of a trademark cannot be requested due to its non-use and revocation decision cannot be made ${ }^{13}$. Pursuant to the second opinion in this regard, the period before the entry into force of the IPL should also be taken into consideration in terms of the duration of non-use in the revocation lawsuits filed after the enforcement of the IPL no. 6769 which have not been rejected and are pending ${ }^{14}$. As a matter of fact, this second opinion is prevailing in the jurisprudence of courts as well as among the scholars. Pursuant to a third opinion, the provision of the IPL which regulates revocation due to non-use of a trademark shall enter into force on 10.01.2024 $4^{15}$.

13 Hayrettin Çağlar, ‘6769 Sayılı Sınaî Mülkiyet Kanununa Göre Tescilli Markanın Kullanılmamasının Hukukî Sonuçları ve Anayasa Mahkemesinin 556 Sayılı KHK M. 14 Hükmünü İptal Eden Kararının Etkileri’ (2017) XXI(1) Gazi University Faculty of Law Review 3-19.

14 Paslı, 'Boşluk Var mı?' (n 2) 492 ff; Paslı, Uluslararası Antlaşmaların Etkileri (n 2) 48 ff.

15 See Ünal Tekinalp and Ersin Çamoğlu, Sinai Mülkiyet Kanunu (Vedat 2017) XXI, XXII. Also see Ünal Tekinalp, 6769 Sayılı Sinai Mülkiyet Kanunu Sempozyumu (Batider 2017) 613, 615. 
Before discussing different ideas on this issue, the reasons for the revocation of the ConC should be examined given that the ConC decision is the basis of the discussions about the commencement date of non-use. Once the reasons for revocation of Trademark Decree art. 14 are identified, the validity of the proposed solutions can be discussed.

\section{A. Justification of the Constitutional Court's Decision Concerning the Revocation of Trademark Decree Art.14}

Paragraphs 11, 12 and 13 of the ConC's decision regarding the revocation of art. 14 explains grounds for the revocation of the article. Pursuant to the relevant paragraphs in the decision;

"11. In the first paragraph of Article 35 of the Constitution, it is stated that every single person has the right to property and inheritance. The second paragraph indicates that these rights can only be restricted by laws and on behalf of public interest. The third paragraph regulates that the exercise of the property right cannot contradict with the benefit of society.

12. In the first paragraph of Article 91 of the Constitution, it is mentioned that "... without prejudice to martial law and state of emergency, the fundamental rights, individual rights and duties of the first and second chapters of the second part of the Constitution and the political rights and duties of the fourth chapter cannot be regulated by decree laws. "Accordingly, it is not possible to regulate property rights provided in the second chapter of the Constitution entitled 'Rights and Duties of the Individual' with a decree law.

13. The subject of the property right is tangible and intangible goods. While movable and immovable goods are within the scope of tangible goods, intellectual and industrial property rights are in the scope of intangible goods. The rights which a trademark provides to its proprietor are called "trademark rights" and these are covered by intellectual and industrial property rights. Therefore, the rule subject to the objection cannot be regulated by the decree law since it is related to the trademark right which constitutes the subject of a property right."

As is seen, the decision clearly states that property can only be restricted by law and it is concluded that the right to a trademark cannot be terminated based on a regulation made under the decree law. In this case, when trying to find a solution to the aforementioned problem, it should be taken into consideration that the property right cannot be restricted by any legislation or decision other than laws ${ }^{16}$.

\section{B. Opinions of and Solutions provided by Scholars about the Possible Solution to the Problem}

The legal status after the ConC decision and the date based on which the period of non-use will be determined has been the subject of discussion among scholars and in practice. For revocation due to non-use, there are basically three opinions about

\footnotetext{
16 Trademark right is not a property right but is an absolute right in terms of the classification of Private Law rights in Turkish Law. However, the Constitutional Court also dealt with the interference with an absolute right within the scope of the regime of interference with the property right.
} 
whether the non-use period begins from the enforcement date of the IPL and about the validity of the periods in general. These opinions are related to the beginning of the periods of non-use to be considered in the action for revocation proceedings initiated after the date of entry into force of the IPL. In fact, there is another view, albeit no longer valid, which has been the subject of a controversy, that there is no problem in terms of lawsuits that are initiated before the enforcement of the IPL and finalized pursuant to IPL art. 9. These views and proposed solutions will be discussed below.

\title{
1. Evaluation of the View that Even the Lawsuits Filed Before the Enforcement Date of the IPL Should not be Rejected
}

One opinion is that there is no problem in terms of the lawsuits initiated during the enforcement period of the IPL and pursuant to the art. 9, a trademark can be revoked ${ }^{17}$. Pursuant to this opinion, the legal gap can be filled by the judges pursuant to Turkish Civil Code art.1 by creating a rule that it would make as a legislator. However, pursuant to the decisions of the Court of Cassation immediately after the Constitutional Court's decision, the ConC's decision should be taken into account in the lawsuits that have been initiated before the ConC's decision and have not yet become final, and the lawsuit should be rejected.

The decision of the $11^{\text {th }} \mathrm{CC}$ of Court of Cassation dated 16.01.2017, with file no. (“F.") 2016/14406, and decision no. (“D.") 2017/263'

\begin{abstract}
"The proceeding is related to the request of invalidity based on the non-use of the trademark numbered 2002/02839 and registered in the name of the defendant, and the court has decided to reject the request for invalidity as a result of the proceedings made in accordance with the revocation of our Chamber. However, it has been understood that the Constitutional Court's decision dated 14.12.2016 and numbered 2016 F., 2016/189 D, which thereafter entered into force through publication in the official gazette dated 06.01.2017, revoked Article 14 of the Trademark Decree. As the said revocation decision of the ConC should be taken into consideration in pending lawsuits without prejudice to acquired rights, justification of the rejection of the lawsuit is deemed appropriate based on its result, and pursuant to Code of Civil Procedure Art. 436, it is required to uphold the decision through amending its justification."
\end{abstract}

As a matter of fact, following decisions are in the same line with the above-cited decision. Pursuant to the decision of the $11^{\text {th }} \mathrm{CC}$ of the Court of Cassation dated 06.05.2019 and 2018/1980 F., 2019/3382 D. ${ }^{19}$;

\footnotetext{
17 Ali Paslı, 'Anayasa Mahkemesi'nin MarkKHK m.14'ü İptal Kararı'nın Etkisi: Kullanmama Gerekçesine Dayalı Hükümsüzlük/İptal Davaları Düşecek Mi?’ (20 January 2017)<www.ticaretkanunu.net/makale-25> accessed 26 June 2019.

$18<$ www.kazanci.com.tr> accessed 24 June 2019.

$19<$ https://karararama.yargitay.gov.tr/YargitayBilgiBankasiIstemciWeb $>$ accessed 24 June 2019. For decisions in the same line, see also decision of the $11^{\text {th }} \mathrm{CC}$ of the Court of Cassation 5286/6916, 05.12.2017; decision of the $11^{\text {th }} \mathrm{CC}$ of the Court of Cassation 13889/7353, 26.11.2018.
} 
"...that the trademark is invalidated due to non-use; however, after the date of decision, the Constitutional Court's decision dated 14.12.2016 and 2016/148 F. and 2016/189 D. revoked Article 14 of the Trademark Decree Law, the said revocation decision should be considered in pending proceedings without prejudice to acquired rights, and that all proceedings instituted on the grounds of non-use under Article 14 of Trademark Decree, including this lawsuit, have lost their legal ground without affecting acquired rights, and that this lawsuit should also be rejected for the same reasons. The decision of the $11^{\text {th }}$ Civil Chamber of the Court of Cassation dated 16.01.2017 and numbered 2016/14406 F.-2017/263 D. accepted the application of the defendant's attorney's appeal and dismissed the lawsuit by rendering a judgment through abrogating the decision of the first-instance court".

In this respect, pursuant to the decisions of the Court of Cassation, it is out of discussion that the lawsuits filed before the date of the ConC decision of 06.01.2017 should be rejected due to the ConC decision.

\section{Evaluation of the Opinion that the Periods before the Enforcement Date of the IPL shall be taken into Consideration in terms of Determination of the Non-Use Period}

Below, we will convey the relevant opinion and our subjective criticisms thereon, followed by an assessment of the judicial decisions regarding this opinion.

\section{a. Explanation of the View}

Pursuant to the second opinion which is adopted by the majority of scholars, the period of non-use prior to the enforcement of the IPL should be taken into consideration in the lawsuits of revocation based on the ground of non-use and filed after enforcement date of the IPL ${ }^{20}$. Pursuant to IPL art.9, it is possible to re-institute the proceedings which are rejected and finalized due to the absence of a provision to be applied after the revocation decision of $\mathrm{ConC}^{21}$. As a matter of fact, decisions of the Court of Cassation and the Court of Appeal approving this view will be examined below.

Advocates of this view claim that, the judge has authority to fill the gap by creating a rule that it would make as a legislator in accordance with Art. 1 of the Turkish Civil Code. The Turkish Civil Code authorizes the judge to create law. Pursuant to this provision, "The law applies to all matters which it refers to with its wording and spirit. In the absence of a provision, the judge shall decide in accordance with customary law, and in the absence of customary, in accordance with the rule that it

\footnotetext{
20 It is stated in the "Current Developments and Problems in the Action for Revocation Due to Non-Use in Trademark Law" held by AIPPI on 9 March 2018, that most of the panelists should also take into consideration of the non-use before 10.01.2017 in revocation proceedings that instituted after the enforcement date of the IPL. See Önder Erol Ünsal, 'Marka Hukukunda Kullanmama Nedeniyle İptal Müessesesinde Yaşanan Güncel Gelişmeler ve Sorunlar Paneli”nden İzlenimler' (11 March 2018) <https://iprgezgini.org/2018/03/11/marka-hukukunda-kullanmama-nedeniyle-iptal-muessesesindeyasanan-guncel-gelismeler-ve-sorunlar-panelinden-izlenimler> accessed 26 June 2019. See also, Paslı (n 17).

${ }_{21}$ See Arzu Oğuz, 'Markanın Kullanmama Nedeniyle İptali Konusunun Yeni Sınai Mülkiyet Kanunu Hükümleri Çerçevesinde Değerlendirilmesi' [2017] 128 Terazi Legal Review 21, 28 ff.
} 
would make as a legislator. The judge, benefits from scientific opinions and judicial decisions in rendering its judgement."

Pursuant to this opinion, the judge may accept that the five-year period commences before the enforcement date of IPL through creating law under the Turkish Civil Code art. 1. There are three grounds for this claim.

First, pursuant to those who adopt this view, the general will of legislator is to sanction non-use with revocation, and therefore judge should fill the gap in line with this intention ${ }^{22}$. However, as will be explained below, the problem is not related to the general will of legislator, but to the form of expression of this will. In addition, as stated in the Court of Cassation's decision to be examined below, accepting that the will of the legislator based on the date of promulgation of laws by Turkish Grand National Assembly is a very forced solution in terms of legal methods.

The second basis underlying the requirement of the judge to fill the gap is based on the provisions and order provided under international agreements. The basis of this claim is the Paris Convention and the TRIPS Agreement. To serve as a reminder, article 5/ C (1) of the Paris Convention reads: "If, in any country, use of the registered mark is compulsory, the registration may be cancelled only after a reasonable period, and then only if the person concerned does not justify its inaction.". Pursuant to TRIPS art. 19/1, "If use is required to maintain a registration, the registration may be cancelled only after an uninterrupted period of at least three years of nonuse, unless valid reasons based on the existence of obstacles to such use are shown by the trademark owner".

The third basis of this opinion is that Article 14 of the abolished Trademark Decree regulated that unused trademarks will be sanctioned with revocation, therefore a period of 5 years plus 4 days will be required for the revocation of an unused trademark registered prior to the enforcement of the IPL, and the reason for the four-day supplementary period being the 4-day period between 06.01.2017 and 10.01.201723. This period is named as a grace period and the reason for this period is based on the fact that there is no obligation to use the trademark in this 4-day period ${ }^{24}$. Pursuant to this view, since there is no responsibility to use the trademark within the 4-day period, the requirement of the ConC decision will be complied with by adding a 4-day period to the periods that have lapsed prior to the enforcement date of the IPL $^{25}$.

\footnotetext{
22 Numan Sabit Sönmez, ‘6769 Sayılı Sınai Mülkiyet Kanununa Göre Markanın Kullanılmaması Neticesinde Ortaya Çıkan Sonuçlar’ (2018) 76(1) Istanbul Law Review 277-308.

23 Uğur Çolak, Türk Marka Hukuku (4th edn, On İki Levha 2018) 998-999; Osman Umut Karaca, Markayı Kullanma Zorunluluğu ve Kullanmamanın Hukuki Sonuçları (Lykeion 2017) 105

24 Karaca (n 23) 105, 106.

25 ibid 106
} 


\section{b. Our Criticisms to the Opinion}

We disagree with the opinion that the general will of the legislator is to envisage a five-year period for revocation and that the judge should fill the legal gap accordingly. The fact that there is only 4 days between the ConC's decision, and the enforcement date of the IPL is not a reason to eliminate the impact of the ConC's decision. Although the will of the legislator is manifested in both the Trademark Decree no. 556 and the IPL as foreseeing revocation as a result of non-use, the ConC has not deemed appropriate that this will is manifested through a decree law.

The problem is the form in which the legislator manifested this will. In the first paragraph of article 35 of the Constitution, it is stated that every single person has the right to property and inheritance. The second paragraph indicates that these rights can only be restricted by laws and for serving a public interest. The third paragraph regulates that the exercise of a property right cannot contradict the benefit of the society. In this case, bearing in mind that the Constitutional Court applies this principle relating to the property right to the trademark right having the character of an absolute right, the restriction of this right can only be made by laws, and therefore introducing such a restriction through a decree law would be contrary to the Constitution. If the property rights and trademark rights considered to be an absolute right are subject to restriction, the manner of this restriction is determined by the Constitution. In demonstrating its will, the legislator must comply with the essential legal norms.

Although the will of the legislator has not changed, since there was no obligation to use the trademark as at the enforcement date of IPL, acting as if such an obligation exists would be contrary to the principle of legal security and certainty, and the requirements of the ConC's decision. In this context, it is inaccurate in terms of legal methods to determine the will of the legislator pursuant to the date of promulgation of a law, as opposed to its publication date. In brief, pursuant to the ConC, it should not be accepted that the right to property (the absolute right on a trademark) which can only be restricted by law, could be restricted by the will of the judge. Moreover, it cannot be accepted that there is a legal gap ${ }^{26}$. Since the rule is obvious: laws do not apply retroactively.

Further, we do not agree that international agreements constitute a basis for creating law. Neither the Paris Convention nor TRIPS foresee an obligation to use the trademark for a period of five years. Under both agreements, the non-use is subject to revocation in cases where the use of the registered trademark is mandatory. While the Paris Convention does not specify a period of time, the TRIPS regulates a period of three years. In other words, both legislations do not require the use of a trademark; and foresee that only in countries where usage of trademark is mandatory a trademark

26 Çağlar (n 13) 16-18; Zeynep Bahadır, Markanın Hükümsüzlüğü ve İptali (Turhan 2018) 242, 243. 
can be revoked due to nonuse "after a reasonable period of time" pursuant to the Paris Agreement, and at the earliest "three years later" pursuant to the TRIPS.

With the Constitutional amendment dated 7 May 2004, a sentence has been added to article 90 of the Constitution of 1982 and the final text of art. 90/3 which reads as follows: "International agreements duly put into effect have the force of law. No appeal to the Constitutional Court shall be made with regard to these agreements, on the grounds that they are unconstitutional. In the case of a conflict between international agreements, duly put into effect, concerning fundamental rights and freedoms, and the laws due to differences in provisions regulating the same matter, the provisions of international agreements shall prevail." 27 . As is seen, if an international agreement is duly enforced, it has the force of $1 \mathrm{law}^{28}$. In other words, the international agreements indicated below that are promulgated by and enforced in Turkey have the status of domestic law, and even the claims that they are unconstitutional cannot be heard.

While this is the case for international agreements, it applies solely to the provisions of international agreements which apply directly. Aybay distinguishes between directly applicable agreements and non-directly applicable agreements: According to the author, the directly applicable agreements could become part of domestic law without need for the national legislator to enact additional legislation; therefore, includes rules that can be applied by courts and other law enforcement officials. On the contrary, the addressee of the provisions of a treaty that are not directly applicable are not legal practitioners but the legislature instead. National law enforcers are not obliged to directly apply agreement provisions that are not directly applicable. For such an application, there is a need for a legislative act (law) to ensure that the provisions of that treaty are applied at the domestic level ${ }^{29}$.

In case of a conflict occurs between a Turkish law and a non-directly applicable treaty provision concerning "fundamental rights and freedoms", such a conflict would be out of the scope of the sentence added to Article 90. Since in such a case, the court has only one provision (the provision of the law), not two separate and

\footnotetext{
In May 2004, the Constitution was amended for the eighth time by the Law No. 5170 dated 07.05.2004, OG 22.5.2004/25469. See Necmi Yüzbaşığlu, 'Mayıs 2004'de Anayasanın 90'ıncı Maddesine Eklenen Hükmün Türk Anayasallık Blokuna Etkileri Üzerine Bir Değerlendirme', in Öget Öktem Tanör (ed), Bülent Tanör'e Armağan (Legal 2004) 782 ff.; Derya Belgin, ‘Anayasa'nın 90. Maddesinde (7 Mayıs 2004) Yapılan Değişikliğin Getirdiği Sorunlar ve Çözüm Önerileri' (2008) 66(4) Ankara Bar Review 110-113; Rona Aybay, 'Uluslararası Anlaşmaların Türk Hukukundaki Yeri’ (2007) 70 Turkish Bar Association Review 187-213.

28 Pursuant to the decision of the $11^{\text {th }} \mathrm{CC}$ of the Court Cassation 6046/8539, 04.06.2007, "The last paragraph of Article 90 of the Constitution of the Republic of Turkey, contains a provision regulating that "International agreements duly put into effect have the force of law.". Although the provisions of the TCC (Turkish Commercial Code) concerning transportation are still in force, although the CMR Convention governing international transports, which came into force after the TCC, and became an internal law rule should be applied as a priority, the judgement rendered through the application of the provisions of the TCC and excluding the provisions of the mentioned Convention based on unlawful grounds was not deemed correct.". In the same direction, see decision of the $11^{\text {th }}$ CC of the Court Cassation dated 25205/9678, 28.09.2019; decision of the $11^{\text {th }} \mathrm{CC}$ of the Court Cassation dated 2970/4599, 07.04.2008.

29 Aybay (n 27) 206, 207.
} 
binding provisions having the same force which may apply to the same issue; and therefore, there is no question of a "conflict of law" regarding fundamental rights and freedoms. In such a situation, the non-directly applicable agreement provision can only assist in the interpretation of the legal provision ${ }^{30}$.

The Paris Convention and the TRIPS, whose provisions are cited above, are not directly applicable agreements ${ }^{31}$. The provisions in these agreements may find application only if the Turkish law stipulates an obligation to use a trademark. However, the compulsory obligation to use a trademark was abolished with the decision of ConC.

One opinion of scholars argues that, as a consequence of the decision of the ConC, it needs to be acknowledged that there is a legal gap in the IPL which needs to be filled by the judge taking the Turkish Civil Code art. 1, the Paris Convention and the TRIPS agreement as basis ${ }^{32}$. However, in our opinion, although the authority of judge to fill a legal gap and create law is accepted by the legal order, bearing in mind art. 35 and 91 of the Constitution, granting such an authority to the judge would violate the principle of legal certainty. It is unacceptable for intellectual property rights that are subject to the regime of the property rights to be restricted merely and directly by a judge's decision in the face of express provisions of the Constitution stated above and the decision of ConC. While it is stated that the restriction of the right to property may only be introduced by law (not even with a decree law), it should be out of question for a judge to restrict the right to property.

We do not agree that the effect of the ConC is limited to the addition of a 4-day period to the periods that have lapsed before the enforcement date of the IPL. As mentioned above, it should be accepted that the obligation for a trademark holder to use the trademark commences as of the enforcement date of the IPL. The reason is that, with the revocation of Article 14 of the Trademark Decree by the ConC's decision, such a provision no longer exists. As stated in the decisions of the Court of Cassation ${ }^{33}$, it should be accepted that all lawsuits initiated on the grounds of nonuse in accordance with Article 14 of Trademark Decree, lost their legal grounds. Likewise, after the ConC's decision, aside from the acquired rights, the obligation to use a trademark for 5 years no longer has a legal basis. The impact of the ConC's decision is not limited to the addition of 4 days to the period before the enforcement date of IPL, as argued in this opinion; with the ConC decision, the legal basis of the obligation not to use the trademark for 5 years has been abolished.

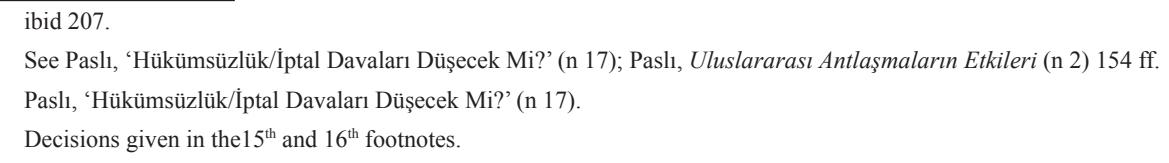




\section{c. Judicial Decisions}

In its below decision, the Court of Cassation has rendered a decision stating that the non-usage terms prior to the enforcement of the IPL should be taken into consideration.

Pursuant to the Court of Cassation $11^{\text {th }}$ CC file no. 2019/1765, decision no. 2019/4421 and dated 14.06.2019:

"In principle laws do not retroactively apply and instead have their consequences proactively, notwithstanding the Turkish Grand National Assembly is not prevented from enacting laws that apply retroactively. Even though it is understood that the statutory provisions governing revocation and defenses due to non-usage under the IPL no. 6769 is understood to be enforceable as of the date of its publication in the Official Gazette due to the absence of a specific provision governing its date of enforcement, bearing in mind that the Law has been published in the Official Gazette on 10.01.2017 but has been enacted on 22.12.2016, as the Constitutional Court order revoking art. 14 of the abrogated Trademark Decree was published in the OG on 06.01.2017 and enforced on this date and hence this provision was in force up until this date, given that the legislator's will relating to the enactment date of the IPL was formed on 22.16.2016 [sic], that it should be accepted that the legislator was mainly aiming to foresee that a trademark would be revoked retroactively due to non-usage, and that the legal gap relating to enforcement after the Constitutional Court's decision which could not have been foreseen should be filled in this manner (see Numan Sabit SÖNMEZ, "6769 Sayılı Sinai Mülkiyet Kanununa Göre Markanın Kullanılmaması Neticesinde Ortaya Çıkan Sonuçlar, The Consequences of Non-Usage of Trademark pursuant to the Industrial Property Law No. 6769", IHFM, No. 76(1), p. 283 ff., accessed on httsp: //dergipark. Ork. Tr/download/article-file / 545172), as it is understood that neither the decision of the court of first instance on the lawsuit initiated on 10.07.2017 having assessed that IPL no. 6769 is enforced retroactively encompassing the period prior to its date of enforcement, and ruling on the revocation of the trademark due to having revealed that it has not been used by the trademark owner in a serious manner with respect to the goods and services for which the trademark was registered during the previous five year period within Turkey, nor the decision of the Court of Appeal rendered upon the appeal of the former decision rendered after conducting an assessment dismissing the appeal request with prejudice are found inappropriate bearing in mind that the legal principles that need to be applicable to the dispute at hand, and that these decisions are in conformity with procedure and laws, in the absence of grounds for the application of art. 369/1 and 371 of the Civil Procedure Code, it has become necessary to rule for the APPROVAL of the decision of the Court of Appeal."

In our opinion, the conclusion derived through the cited Court of Cassation decision is in line with the ideal legal consequence that needed to be reached through including a specific provision in the IPL governing enforcement with respect to revocation of trademarks; notwithstanding is not lawful. Bearing in mind that laws enter into force through announcement in the Official Gazette, and unless foreseen otherwise, govern events after their date of enforcement, alleging that the legislator's will is to enforce the Law as of its date of promulgation would damage the principal of legal certainty. 
The decision of the Antalya Regional Court of Justice (Court of Appeal) $1^{\text {st }} \mathrm{CC}$ with file no. 2017/1248, decision no. 2017/1555 and dated 29.12.2017 is as follows:

"As foreseen in article 90/ultimate paragraph of the Constitution, international agreements duly put in force have the force of law. In fact, no application can be made before the Constitutional Court against these [agreements] due to violation of the Constitution. The Constitution therefore foresees that a principle foreseen in international agreements legally have the force of "Law" and has not accepted them as inferior with regards to the "hierarchy of norms". It could therefore be concluded that granting the provision of an international agreement the force of law is a constitutional obligation (decision of the Assembly of Civil Chambers dated 09.12.2015 with file no. 2015/10-1824 and decision no. 2015/2903).

Art. 5/C-1 of the Paris Agreement and art. 19/1 of TRIPS, which are international agreements that have been enforced in line with article 90/ultimate paragraph of the Constitution have the force of law, and thus the court of first instance's justification based on the lack of a legal provision that could apply to the case at hand is not accurate, and as it has been understood that the court has rendered its decision without regard to these provisions, without collecting evidence submitted by the parties relating to the merits of the lawsuit, the defendant's appeal of the decision of the Court of First Instance is granted by its merits...'

Notwithstanding, we are of the opinion that this decision has overlooked the fact that the art. 5/C-1 of the Paris Agreement and art. 19/1 of TRIPS are not directly applicable provisions. The reason is that, in order for an international agreement to have the force of law, its provisions need to introduce substantive principles as do the statutory provisions. Nevertheless, as stated above, the said provisions do not entail an obligation to use the trademark. Instead, they state that the consequence of non-usage where there is an obligation to use is revocation. Moreover, the Paris Agreement has not specified a specific term of non-usage, while TRIPS has stated that this time period needs to last for at least three years. In conclusion, albeit in line with de lege feranda, the decision is not in line with the conditions for the application of international agreements. Indeed, a decision of the same Antalya $\mathrm{CoA} 16^{\text {th }} \mathrm{CC}$ rendered in May, it has expressly declared having abandoned its opinion specified above.

\section{Evaluation of the Opinion that the Periods Lapsed prior to the Enforcement Date of the IPL shall be Taken into Consideration in terms of Determination of Non-Use Period}

\section{a. Explanation of the View}

As is known pursuant to art. 152/3 of Constitution, revoked laws are abolished as of the date of publication of the Constitutional Court's revocation decisions in the Official Gazette. If necessary, the Constitutional Court may also stipulate the date of enforcement of its revocation decisions. This date cannot exceed one year as from publication of the decision in the Official Gazette. Also pursuant to Art. 152/5 
of the Constitution, a revocation decision is not retroactively applicable. Hence, the decision on the revocation of art. 14 of Trademark Decree is effective as from 06.01.2017 which is the date of publication of the decision in the Official Gazette. In other words, the non-use of a trademark for a period of five years or longer cannot accepted as grounds for revocation of the trademark from 06.10.2017 onwards. By coming into force 4 days after the publication of the above-mentioned decision in the Official Gazette, the IPL reintroduced the obligation of using trademark.

Pursuant to the view that we also share, as long as an enforcement provision is not added to the IPL, the periods of non-use prior to 10.01 .2017 cannot be taken into consideration ${ }^{34}$. The reason is that, the article that foresaw revocation as a consequence of the non-use of a trademark is revoked with the ConC decision dated 06.01.2017. In this case, the revocation of trademark as a legal institution was not in force as at the enforcement date of the IPL ${ }^{35}$. On the other hand, a law is applicable to events that occur after the date of its enforcement, and as a rule, it cannot apply retroactively; unless an enforcement provision is regulated where it is clearly stated that it will also apply to the events that occurred before the law entered into force ${ }^{36}$.

The rule of law provided for in art. 2 of the Constitution refers to a state that is based on human rights, who protects and strengthens these rights and freedoms, whose acts and transactions are in accordance with law, who maintains and develops a fair legal order in every field, establishes legal security, avoids situations and attitudes incompatible with the Constitution, renders the law sovereign to all state organs, and is open to judicial control.

The principle of legal security, which a state of rule of law is obliged to ensure, is the common value that requires legal norms to be predictable, that individuals can trust the state in all their acts and transactions, that the state avoids methods that damage this sense of trust in legal arrangements, and that is protected in fundamental rights guarantee. As a rule, legal security obliges non-retroactivity of laws. Therefore, since the laws can be applied to legal situations after the date of their enforcement in accordance with the 'principle of non-retroactivity of laws', a subsequent law does not apply to events prior to the date of its enforcement ${ }^{37}$.

Çağlar (n 13) 12 ff.

35 Karaca, on the other hand, acknowledges that, while as a rule, the laws are applicable to events that occurred between the date of enforcement and the dates of their abolition, the new rules may also apply to events that commence to take place in advance and continue to take place on the date of enforcement of the new regulation. See Karaca (n 23) 103-105. We will discuss below which laws can be applied to existing rights. See below, no. 3 .

36 For example, there are special regulations in Articles 3 and 4 of the Law on the Enforcement and Application of the Turkish Commercial Code with regard to its application to the events before the entry into force of the Turkish Commercial Code No. 6102. Therefore, which events that took place when the old law (this term was used by the Code) was in force would be subject to the provisions of the TCC no. 6102 .

${ }_{37}$ For the ConC's decision see Application No: 2014/15237 Date of Decision: 25/7/2017, OG 2.8.2017/30142; <www. kazanci.com.tr> accessed 25 June 2019. 
Art. 192 of the IPL is an enforcement provision and does not contain any regulation that permit the IPL to be applicable to past events. On the contrary, it is indicated that the provisions except articles 23, 26, 46 and 69 -hence, including art. 9 of the IPL- will enter into force on the date of publication of the IPL. The consequence of the non-retroactivity of laws is that the period for the obligation to use starts from the date of enforcement of the IPL. Pursuant to art. 9 of the IPL, the five-year period of non-use shall be calculated only from the date of entry into force of this Law, in other words from 01.10.2017. Thus, it was stated by the authors who adopted this view that Court of Cassation decisions were in this direction ${ }^{38}$. As a result, action for revocation based on the non-use of a trademark may be filed only as of 10.01.2022. However, pursuant to art. 192/1-a of the IPL, the provision regarding the revocation of a trademark by applying to the Turkish Patent and Trademark Office ("TPTO") will enter into force 7 years after the publication date of IPL. In other words, the authority of the TPTO to revoke will begin in the year 2024 (art. 192/a governing enforcement). Until this authority of the TPTO comes into force, the authority to revoke shall be exercised by the courts in accordance with the principles provided in this article (Provisional art. 4 of the IPL). In the event that the legal regulations are adhered to, revocation cannot be requested based on the non-use of a trademark until 10.01.2022 $2^{39}$. After this date, this request may be made before the courts; and as of 10.01.2024, this request can be made before the TPTO.

In our opinion, the most reasonable solution to this problem is to add a provision to the enforcement article in the IPL and ensure that the periods that lapsed prior to the entry into force of the IPL are taken into account. However, it is useful to approach the situation in terms of the Constitution ${ }^{40}$. In some cases, the legislator introduces provisions governing enforcement for a later enacted law to be valid from the date of entry into force of a Constitutional Court's revocation decision. However, as stated in the ConC decisions, "As a rule, the legal security that the rule of law is obliged to ensure requires that in principle the laws are not retroactive. Pursuant to the principle of non-retroactivity of laws, laws shall be enacted in principle to be applied to events, proceedings and acts after their effective date, except for certain exceptional cases, such as the protection of acquired rights and the improvement of financial rights required by the public interest and public order. ${ }^{41}$.

In practice, statutory provisions which have adopted effective dates starting from the revocation decision of the Constitutional Court, despite their subsequent entry into force, have generally not been subject to a dispute. Particularly, as stated in the ConC

\footnotetext{
38 See decisions provided in the $18^{\text {th }}$ and $19^{\text {th }}$ footnote.

39 Çağlar (n 13) 15 ff; Bahadır (n 26) 242-243.

40 For detailed and comprehensive information on this issue, see Özen Ülgen, Anayasa Yargısında İptal Kararlarının Etkileri (On İki Levha 2016) 162 ff.

41 ConC decision 82/66, 30.05.2006. See ibid.
} 
decision mentioned above, the retroactive application of laws in cases where public interest and public order require is accepted. However, in particular, the acceptance of the retroactive application of unfavorable provision was deemed to be contrary to the principle of the rule of law and was subject to revocation by the $\mathrm{ConC}^{42}$.

As a matter of fact, Çolak also states that the right to property cannot be interfered with by the judge replacing the legislator and creating a law, that the legal gap arising from the revocation decision of the Constitutional Court cannot be filled in this way ${ }^{43}$.

In our view, as a requirement of the principle of the rule of law, an article should have been inserted into the IPL in order commence the enforcement in advance, starting from the decision of the Constitutional Court dated 06.01.2017. However, unless this is done, in our opinion, it is not possible to extend the obligation to use to the periods lapsed before 10.01.201744. Although this state of legislation disturbs our sense of justice, facts including the effects of the revocation decision of the Constitutional Court, the scope of the enforcement article of the IPL, the relevant right having the character of an absolute right and that the interference in an absolute right cannot be ensured by the judge creating a law should not be ignored.

\section{b. Judicial Decisions}

As is the case among scholars, the jurisprudence of courts was also divided into two after the ConC decision. While pursuant to some of the judgments, it is not possible to take into account the periods lapsed prior the entry into force of the IPL due to the ConC decision, pursuant to other decisions, there is no legal gap bearing in mind the existence of international agreements and the provision of 90/3 of the Constitution, and the periods of non-use, even before the date of entry into force of the IPL, shall be taken into consideration.

The following decision states that the periods of non-use should be commenced from 10.01.2017 and that the periods of non-use for prior to the entry into force of the IPL shall not be taken into consideration. Çolak also stated in his book that the application of the $16^{\text {th }}$ Civil Chamber of the Istanbul Court of Appeal was in this direction, but he did not present a precedent ${ }^{45}$.

Pursuant the decision of Istanbul $2^{\text {nd }}$ Civil Court of Intellectual and Industrial Property Rights 2017/18 F., 2017/199 D., dated 24 October 2017,

\footnotetext{
2 Pursuant to ConC decision 42/44, 27.05.2003; "For the reasons explained, it is not fair to mention that in the rule of law, which is obliged to establish and maintain a fair legal order, a regulation which results unfavourable is just as it is in the objection rule. The rule is contrary to Article 2 of the Constitution. Revocation is required.". See Ülgen (n 40) 165-166. Also see Çağlar (n 13) 12.

43 Çolak (n 23) 999.

44 Çağlar (n 13) 14; Bahadır (n 26) 243-244.

45 Çolak (n 23) 998.
} 
"Even though there is a similar provision in Article 19 of TRIPS which Turkey is a party to, bearing in mind that this provision can be applicable in the presence of obligation to use a trademark, that after the revocation of Art. 14 of Decree-Law no. 556there is no obligation to use the trademark for the period before the date of 10.01.2017, which is the effective date of IPL, that it is not possible to apply provisions of TRIPS for this period, that even though Article 9 of the Industrial Property Law no. 6769, which entered into force after the revocation decision and was in force on the commencement of the date of this lawsuit, stated that if, within a period of five years following the date of registration, the trademark has not been put to genuine use in Turkey by the trademark proprietor in connection with the goods or services in respect of which it is registered, or if such use has been suspended during an uninterrupted period of five years, the trademark shall be revoked unless there are proper reasons for non-use, this provision may apply after the enforcement date of the Law, bearing in mind that the defendant did not have an obligation to use its registered trademark before the effective date of the IPL, and that because of the revocation decision of Constitutional Court the period of 5 years has not expired after the enforcement date of IPL, it has become necessary to rule for the REJECTION of the lawsuit."

As it can be seen, it was stated that the non-use obligation could only be taken into consideration as of the effective date of the IPL during this early period when the IPL entered into force and the duration of prior non-use should not be taken into account.

\section{The View that Art. 9 of the IPL will not Enter into Force Until 10.01.2024}

Pursuant to another view among scholars, an action for revocation based on Article 9 of the IPL may be initiated after 7 years from 10.01.2017 ${ }^{46}$. However, in our opinion, bearing in mind the provisional article 4 of the IPL, this view cannot be defended. Pursuant to the enforcement provision of the IPL, which is art. 192/1-a, article 26 of the IPL shall enter into force seven years after its publication. Article 26 of IPL regulates the revocation of a trademark by the trademark office due to its non-use, and not the invalidity of the trademark. Until the effective date authorizing the TPTO, the authority to revoke will be exercised by the courts pursuant to the principles provided in this article (Provisional art. 4). In other words, the action for revocation based on non-use will theoretically be filed before the Courts until 2024. However, due to the decision of ConC and the lack of necessary provisions in the IPL, it will be possible for the courts to decide for revocation based on non-use only after 5 years from the date of entry into force of the IPL. In other words, the courts will be able to decide on the revocation of the trademarks until the authorization issued in Article 26 of the IPL passes to the TPTO. Therefore, the institution of revocation of a trademark was granted to the TPTO and this authority of the TPTO starts in 2024. It is understood from the provisional article 4 of the IPL that the courts are (theoretically) competent until that date.

$\overline{46}$ Tekinalp and Çamoğlu (n 15) XXI, XXII; Tekinalp (n 15) 613, 615. 


\section{E. The Effect of the Debates about the 5-Year Non-Use Period in terms of Revocation on the 5-Year Usage Requirement Required in Lawsuits of Opposition and Infringement on Trademark Right}

As mentioned above, when the revocation is requested based upon non-use of the trademark, it is stated that the period of non-use should be calculated as of 10.01.2017. However, when we examine the law, not only article 9 of the IPL, article $19 / 2$ regulates the "defense of non-use in the opposition proceeding", article $25 / 7$ governs the "defense of non-use in the invalidation proceeding" and article 29/2 foresees the "defense of non-use in the infringement proceeding".

The main question here is whether taking into consideration of 5-year period from the effective date of the IPL for the revocation of a trademark due to its non-use will be applied to "non-use defenses" in the same way.

\section{Regulations in relation to the Defense of Non-Use}

\section{a. Non-Use as a Defense in Opposition to a Trademark}

The right on a registered trademark is known to be a monopoly right. However, this right has some limitations. Pursuant to the IPL, the use of a trademark is mandatory in order to claim the monopoly right thereon against third parties. As a matter of fact, the defense of non-use was introduced into Turkish Law with the provision of the IPL art. 19/2. Pursuant to this provision, "Regarding oppositions filed in the scope of the first paragraph of Article 6, provided that the trademark, which is the ground for opposition, has been registered for at least five years at the date of application or date of priority of the application for which the opposition is filed, upon the request of the applicant, it shall be requested from the opponent to submit evidence proving that it had genuinely used its trademark on the goods and services relating to the opposition during the five-years period before the date of application or the date of priority of the latter application or whether it has a proper reason for not using its trademark during that period. In case the opponent fails to prove the aforesaid, opposition shall be refused. If it is proven that the trademark, which is the ground for opposition, has been used only for some of the goods or services which are covered by registration, then the opposition shall be examined taking into account the goods or services whose use is proven.".

As stated in the legislative justification of this article, this provision introduces a new regulation which was not included in Trademark Decree. Pursuant to the provision, in the case of oppositions filed within the scope of the first paragraph of Article 6, the applicant, under certain conditions, may request the opponent to submit evidence that it had genuinely used its trademark. The paragraph also regulates the 
result of the failure to submit the evidence requested by the party opposing to the publication within the prescribed time limit. With this regulation, it is aimed to ensure the effective use of registered trademarks in the market and to prevent the use of the opposition to publication in a rambling or malicious manner. As can be seen, the prior trademark proprietor must have used its trademark in the last five years in order to object to the next registration application.

\section{b. Non-Use Defense in Invalidation Proceedings}

A similar provision is provided for the invalidity of a trademark. The IPL art. 25 regulates the invalidation lawsuit in general. Pursuant to this provision, the prior trademark proprietor, who relies on absolute and relative grounds for refusal, has the right to demand the invalidity of the registration of the next trademark.

Pursuant to the Art. 25/7 of the IPL, "In the invalidation proceedings filed pursuant to first paragraph of Article 6, the provision of second paragraph of Article 19 may be asserted as a defense. In this case, date of proceeding shall be taken as the basis in determining the five-year period regarding use. If the plaintiff's trademark has been registered for at least five years at the application date or at the date of priority right of trademark for which invalidation is requested, the plaintiff shall also prove the fulfillment of the conditions specified in the second paragraph of Article 19 at the aforesaid date of application or date of priority right.".

When we examine the legislative justification of art. 25 of the IPL, it is regulated that in the invalidation proceedings filed under art. 6 of the IPL, the second paragraph of article 19 may be asserted as a defense, but in this case the motion date shall be taken as the basis for the determination of the five-year period of use.

In this case, if a person who faces an invalidation proceeding under art. $25 / 1$ of the IPL claims that the other party has not used the trademark genuinely in the last five year period and the person who files the invalidation lawsuit cannot prove genuine use, the invalidation lawsuit will be dismissed. In fact, the right of the person who files an invalidation lawsuit based on its monopoly right depends on the genuine use of its trademark. If there is no genuine use, the person has no right to initiate a lawsuit.

\section{c. Non-Use Defense in Infringement Proceedings}

Pursuant to the Art. 29/2 of the IPL, Provisions of second paragraph of Article 19 may be used as a defense in infringement proceedings. In this situation, the date of the proceeding shall be taken into account for determining the five-year period related to the use. 
Pursuant to the IPL art. 29/2, if a trademark is registered, the trademark proprietor has the right to file a lawsuit for infringement if the same or similar trademarks are used for the same or similar goods and services. After the lawsuit is filed, the person who is sued for infringement may request evidence of the use of the claimant. If the prior registered trademark proprietor fails to prove that the use of the trademark was not suspended for a period longer than five years retrospectively as of the date of the lawsuit, then the lawsuit is rejected. A person who has been sued for infringement may request that it be proven that the trademark shown as a basis for the proceeding has been used genuinely in the last five years with respect to the relevant goods/ services. The fact that a trademark is registered is not sufficient to file the lawsuit or for the acceptance of a lawsuit; the trademark must also be used genuinely in the last five years. Certain rights granted to the registered trademark are subject to the genuine use of the trademark. If it is proven that the trademark which is the ground for infringement is used for only a part of the goods or services within the scope of its registration, the lawsuit shall be examined only on the basis of the goods or services proven to be used. Even if registered, it cannot be claimed that subsequent use constitutes an infringement for a trademark which has not been used in the last five years.

As it is seen, the prior trademark proprietor must have used its trademark seriously in the last five years in order to institute proceedings against subsequent use.

\section{The 5-Year Period for the Non-Use Defense Commences Before the Date When the IPL Enters into Force}

Although we acknowledge that the provisions of the IPL will not apply retroactively with respect to the termination of a trademark, we accept that the provisions of the IPL shall apply to the existing property rights in terms of the non-use defense. The reason for our view is the different types of consequences that apply to a right.

As mentioned above, laws apply to events that have occurred after their effective date. This is also accepted and applied by the decisions of the Constitutional Court ${ }^{47}$. In order for a new law to affect a previous situation, there must be a right or act that exists/maintains its effect in the enforcement period of the said law. In other words, only a permanent right or action can be influenced by a subsequent norm. These rights, which continue in the periods of enforcement of different legislations and are open to external influences (new developments), can be considered as living social organisms (status). Although they may have been subject to legal acts, these statuses are open to new acts. The new law will concern them in future. Permanent rights will be affected by new laws. Property right can be shown as an example for

47 Constitutional Court decisions 13/23, 31.05.1973; ConC decision 137/71, 11.12.1964, for this decision see Constitutional Court Decisions Review No. 2, 1971. 
permanent rights. The underlying reason is that, the property right is a right that exists and continues. These rights will remain in force even if the legislation in force at the time they were originated to which they were subject to is abolished, but the rules and provisions of the new law will apply for their continuity and termination. When mandatory provisions of law are concerned in legal areas where the freedom of contract does not apply (such as marriage, employment contract, property right, social security acts, consumer protection), the provisions of the new law shall apply immediately to the present situation ${ }^{48}$.

As a matter of fact, considering the decisions of the ConC, it is stated that the application of new regulations in terms of permanent rights is not in contradiction with the "principle of non-retroactivity of laws". One of the indispensable elements of the principle of the rule of law provided under article 2 of the Constitution is that the laws should ensure legal security and that it must include predictable rules for the future. Therefore, in order to maintain trust and stability in the rule of law, as a rule, laws apply to events after the date of their entry into force. Pursuant to the principle of non-retroactivity of laws, laws shall be enacted in principle to be applied to events, proceedings and actions after their effective date, except in certain exceptional cases, such as the protection of acquired rights and the improvement of financial rights as required by the public interest and public order. It is one of the general principles of law that the enacted laws do not affect the past and certain legal situations ${ }^{49}$.

The principle of respect for acquired rights is one of the general principles of law and is a result of the principle of legal security. In order to be able to speak of an acquired right, this right must be de facto acquired with all its consequences pursuant to the rules in force prior to the enforcement of the new law. An acquired right is the right that arises from the status of a person, which has become definite and transformed into a personal nature. Expectant rights based on a status and thus prospective do not have this character. It cannot be argued that these amendments are contrary to the principle of the rule of law, unless the amendments to the law affect the rights acquired and damage the legal security ${ }^{50}$.

In accordance with the decision of the Constitutional Court, considering that the regime of property right will be applied to trademark rights; the property right must be

\footnotetext{
48 For detailed explanation in this regard, see Ali Nazım Sözer, 'Kanunların Önceye Etki Yasağı: Sosyal Sigortalar Hukuku Bakımından bir Değerlendirme' $<$ https://journal.yasar.edu.tr/wp-content/uploads/2014/01/9-Ali-Naz\%C4\%B1mS\%C3\%96ZER.pdf> accessed 26 June 2019; Başak Baysal, ‘Kanunların Zaman Bakımından Yürürlüğü', in Rona Serozan (ed), Prof. Dr. Necip Kocayusufpaşaoğlu için Armağan (Adalet 2004) 475-503; Muhammet Özekes, 'Özel Hukuk-Kamu Hukuku ve Yargılama Hukuku Bakımından Kanunların Zaman İtibariyle Uygulanması' in Sabih Arkan (ed), Prof. Dr. Firat Öztan'a Armağan (Turhan 2010) 2759-2875; Tekin Akıllığlu, 'Yasaların Zaman Bakımından Uygulanmasına İlişkin Bazı Sorunlar' < www.todaie.edu.tr/resimler/ekler/1a35a99dcbf3818_ek.pdf?dergi=Amme\%20Idaresi\%20Dergisi> accessed 26 June 2019.

49 ConC, Application No: 2013/1426, Date of Decision: 25.03.2015, OG 18.06.2015/29390 (<www.kazanci.com.tr> accessed 25.06.2019).

so ibid.
} 
limited in accordance with the letter and spirit of the Constitution, and in this context, the additional guarantees provided for this right must be respected and this right must not be restricted for purposes other than in the public interest, and should also be limited conforming to the principle of proportionality without infringing on their essence. In the decisions of Constitutional Court on the property right, these criteria are often applied together and the fair balance between the right of an individual and the public interest is emphasized ${ }^{51}$. At this point, the seriousness of self-sacrifice must be taken into account, bearing in mind public interest which constitutes the basis of the alleged violation ${ }^{52}$.

Intangible rights were recognized as property rights for the first time with the decision of Constitutional Court dated 31.01.2008 numbered 2004/81 F., and $2018 / 48$ D. To the extent that a trademark is recognized as the subject of a property right, the rules on the property right must also apply to the trademark. Pursuant to the ConC decisions, it is necessary to examine whether the laws can retroactively apply in terms of revocation and the non-use defense. When it is recognized that the revocation of a trademark terminates a property right and that this termination can only be realized by law, it is necessary to acknowledge that the first statutory legislation in this direction is the IPL. From this point, although there is the institution of "revocation based on non-use" in Turkish Law within the scope of Trademark Decree which has been subject to widespread judicial practice, this fact should not be misleading: the Constitutional Court revoked Trademark Decree Art. 14 for the protection of the property right; consequently, the application of the high judiciary which has been established pursuant to this provision has been excluded. Therefore, before the enactment of the IPL, since there was no obligation to use the trademark, the termination of the property right due to non-use is contrary to the Constitution and the principle of non-retroactivity of Laws.

Since the rule of termination of a trademark right after five years of non-use is regulated for the first time as a law under the IPL, and the trademark right is an acquired right in the sense adopted by the Constitutional Court, it must be accepted that the period for termination of this right is introduced by IPL ${ }^{53}$.

However, provisions relating to non-use defenses do not regulate the termination of a person's trademark right. These provisions relate to changing the terms of use of an existing property right. In this case the right is not terminated, the exercise of the right is subject to certain conditions: that a person has exercised its right in order to be able to object to or to terminate another's right. This, as stated in the ConC decisions,

51 ConC decision 33/51, 29.12.1999.

52 ConC Application No: 2013/1426, Date of Decision: 25.03.2015, OG 18.06.2015/29390 (<www.kazanci.com.tr> accessed 25.06.2019).

53 cf. Karaca, (n 23) 103-105. 
is a regulation that does not infringe on the essence of the right and conforms to the principle of proportionality. It has been acknowledged that the property right of a trademark proprietor has not been abolished, that the person can use the trademark again, but cannot interfere with the rights of others on a limited basis.

It should not be forgotten that the provision stating that the trademark right will be revoked if it is not used for 5 years regulates the termination of an absolute right, a property right pursuant to the Constitutional Court. This provision entered into force via a law for the first time on 10.01.2017. Before this provision, the Constitutional Court ruled that non-use of a trademark by the trademark proprietor could not be a reason to terminate its property right. Therefore, the abolishment of the essence of the property right regarding non-use is introduced by the IPL dated 10.01.2017. The law enacted on the abolishment of the essence of property should not have any retroactive effect and the result of "revocation" should not be attributed to the previous non-use. However, the defense of non-use regulates the condition of using a property without infringing on the essence of the property. The distinction between revocation and non-use focuses on whether or not the essence of a trademark right (property right) is infringed on. In the case of a revocation, the essence of the right is affected, whereas when the defense of non-use is concerned, no interference is made with "the right to be used in accordance with the core functions" which is inherent in the essence of the trademark. The trademark proprietor may use its trademark on its goods / services in order to differentiate itself, but if it has not used its trademark, it cannot effectively prevent the application, registration and use of others.

As a result, in our opinion, the provisions governing the trademark proprietor's right to use the trademark right can be applied to an ongoing property right within the scope of "non-use as a defense in opposition proceedings" regulated under art. 19/2, "non-use as a defense in invalidation proceedings" regulated under art. 25/7 and "non-use as a defense in infringement proceedings" regulated art. 29/2 of the IPL. The period of non-use sought in these regulations may be extended to the period preceding the enforcement of the IPL.

\section{Conclusion}

Only four days prior to the entry into force of the Industrial Property Law, the Constitutional Court created a gap by revoking Article 14 of Trademark Decree no. 556 , which regulates the violation of the obligation to use the trademark. Thus, there was a confusion on the date of the entry into force of the IPL, since at that date there was no obligation to use the trademark and in particular due to the lack of a provision foreseeing the retroactive application of the IPL. As a result of the application of the laws to the events occurring after their effective dates, it should be accepted 
that the obligation to use the trademark commenced as of 10.01.2017. However, the obligation to use the trademark and the result of non-compliance with this obligation is also accepted by international conventions.

In order to solve this problem and to accept the obligation to use in the period before the effective date of the IPL, different views were developed among scholars. However, in our opinion, such an evaluation by the judge would be contrary to the decision of the Constitutional Court and the art. 35 and 91 of the Constitution that form the basis of this decision. Therefore, the judge should not decide in line with a property restriction that is not provided in the law on the basis of art. 1 of the Turkish Civil Code. In our opinion, the most appropriate and legally sound solution would be to add an enforcement provision to the IPL indicating that the IPL would also apply to the events before it came into force. Faced with the fact that no such enforcement provision is provided in the IPL, it should be acknowledged that an action for revocation cannot be filed before the date of 10.01.2022. With the decision of the Court of Cassation on 14.06.2019, which is a recent decision, it has been decided that the five-year period can be extended before the date of the entry into force of the IPL. In our opinion, bearing in mind the provisions of the Constitutional Court's revocation decision and the absence of the enforcement provision in the IPL, it is an unlawful decision. We are of the opinion that interpreting the intention of the legislator based upon the date of the adoption of the laws will damage the principle of legal security.

Although the period to be considered for the revocation of a trademark should commence as of 10.01.2017; the proprietor of the trademark should not have ceased using its trademark for a period of 5 years preceding the opposition or initiation of a lawsuit in order to object to the registration application of another's trademark, to request the invalidity of another's trademark, or to object to the use of the same trademark in the trade by another person. The period here should be determined by the date on which the request is made, not by the date on which the IPL entered into force. In this case, non-use before 01.10 .2017 will be considered in defense of non-use.

The reason for the different results in terms of revocation and defense of non-use of a trademark is based on whether the interference was made to the essence of the trademark right, which is considered by the Constitutional Court to be a property right. While the revocation of a trademark means the abolishment of the essence of the trademark right, "the defense of non-use" does not interfere with the right to its use in trade, which is accepted as the essence of the trademark. As a result, the 5 -year non-use period in the provisions regulating the "defense of non-use" will be determined pursuant to the application date that causes to put forward the defense of non-use, not the date of 10.01.2017, which is the effective date of the IPL.

Grant Support: The author received no grant support for this work. 


\section{Bibliography}

Akıllığlu T, 'Yasaların Zaman Bakımından Uygulanmasına İlişkin Bazı Sorunlar' <www.todaie. edu.tr/resimler/ekler/1a35a99dcbf3818_ek.pdf?dergi=Amme\%20Idaresi\%20Dergisi $>$ accessed 26 June 2019.

Aybay R, 'Uluslararası Anlaşmaların Türk Hukukundaki Yeri' (2007) 70 Turkish Bar Association Review 187-213.

Bahadır Z, Markanın Hükümsüzlüğü ve İptali (Turhan 2018).

Baysal B, 'Kanunların Zaman Bakımından Yürürlügü', in Rona Serozan (ed), Prof. Dr. Necip Kocayusufpaşaoğlu için Armağan (Adalet 2004).

Belgin D, 'Anayasa'nın 90. Maddesinde (7 Mayıs 2004) Yapılan Değişikliğin Getirdiği Sorunlar ve Çözüm Önerileri’ (2008) 66(4) Ankara Bar Review 110-113.

Çağlar H, '6769 Sayılı Sınaî Mülkiyet Kanununa Göre Tescilli Markanın Kullanılmamasının Hukukî Sonuçları ve Anayasa Mahkemesinin 556 Sayılı KHK M. 14 Hükmünü İptal Eden Kararının Etkileri' (2017) XXI(1) Gazi University Faculty of Law Review 3-19.

Çolak U, Türk Marka Hukuku (4th edn, On İki Levha 2018).

Karaca OU, Markayı Kullanma Zorunluluğu ve Kullanmamanın Hukuki Sonuçları (Lykeion 2017).

Oğuz A, 'Markanın Kullanmama Nedeniyle İptali Konusunun Yeni Sınai Mülkiyet Kanunu Hükümleri Çerçevesinde Değerlendirilmesi’ [2017] 128 Terazi Legal Review 21-31.

Özekes M, ‘Özel Hukuk-Kamu Hukuku ve Yargılama Hukuku Bakımından Kanunların Zaman İtibariyle Uygulanması' in Sabih Arkan (ed), Prof. Dr. Firat Öztan'a Armağan (Turhan 2010).

Paslı A, Uluslararası Antlaşmaların Türk Marka Hukukunun Esasına İlişkin Etkileri (Vedat 2014).

Paslı A, 'Anayasa Mahkemesi'nin Son Dönemdeki İptal Kararlarının Marka Hukukumuza Etkisi: Boşluk Var mı?' (2016) 12(46) Legal Intellectual and Industrial Property Rights Review 491-520.

Paslı A, 'Anayasa Mahkemesi’nin MarkKHK m.14'ü İptal Kararı'nın Etkisi: Kullanmama Gerekçesine Dayalı Hükümsüzlük/İptal Davaları Düşecek Mi?’ (20 January 2017) <www. ticaretkanunu.net/makale-25> accessed 26 June 2019.

Sönmez NS, '6769 Sayılı Sınai Mülkiyet Kanununa Göre Markanın Kullanılmaması Neticesinde Ortaya Çıkan Sonuçlar' (2018) 76(1) Istanbul Law Review 277-308.

Sözer AN, 'Kanunların Önceye Etki Yasağı: Sosyal Sigortalar Hukuku Bakımından bir Değerlendirme' $<$ https://journal.yasar.edu.tr/wp-content/uploads/2014/01/9-Ali-Naz $\% C 4 \%$ B1m-S\%C3\%96ZER.pdf> accessed 26 June 2019.

Tekinalp Ü and Çamoğlu E, Sinai Mülkiyet Kanunu (Vedat 2017).

Ülgen Ö, Anayasa Yargısında İptal Kararlarının Etkileri (On İki Levha 2016).

Ünsal ÖE, '2018 yılı Avrupa Birliği İlerleme Raporu Fikri Mülkiyet Hukuku Bölümü' < https:// iprgezgini.org/2018/04/18/2018-yili-avrupa-birligi-ilerleme-raporu-fikri-mulkiyet-hukukubolumu/> accessed 26 June 2019.

Ünsal ÖE, 'Marka Hukukunda Kullanmama Nedeniyle İptal Müessesesinde Yaşanan Güncel Gelişmeler ve Sorunlar Paneli”nden İzlenimler' (11 March 2018) <https://iprgezgini. org/2018/03/11/marka-hukukunda-kullanmama-nedeniyle-iptal-muessesesinde-yasananguncel-gelismeler-ve-sorunlar-panelinden-izlenimler> accessed 26 June 2019.

Yasaman H, Altay SA, Ayoğlu T, Yusufoğlu F and Yüksel S, Marka Hukuku 556 sayılı KHK Şerhi (Vedat 2004).

Yüzbaşığlu N, 'Mayıs 2004'de Anayasanın 90'1ncı Maddesine Eklenen Hükmün Türk Anayasallık Blokuna Etkileri Üzerine Bir Değerlendirme', in Öget Öktem Tanör (ed), Bülent Tanör'e Armağan (Legal 2004). 
